Article

\title{
Experimental and Computational Demonstration of a Low-Temperature Waste to By-Product Conversion of U.S. Oil Shale Semi-Coke to a Flue Gas Sorbent
}

\author{
Kathleen Dupre ${ }^{1}$, Emily M. Ryan ${ }^{1,2}$, Azat Suleimenov ${ }^{2}$ and Jillian L. Goldfarb 1,2,3,* \\ 1 Department of Mechanical Engineering, Boston University, 110 Cummington Mall, Boston, MA 02215, USA; \\ kdupre@bu.edu (K.D.); ryanem@bu.edu (E.M.R.) \\ 2 Division of Materials Science \& Engineering, Boston University, 15 Saint Mary's St., Brookline, MA 02446, \\ USA; azat@bu.edu \\ 3 Department of Biological and Environmental Engineering, Cornell University, 226 Riley-Robb Hall, Ithaca, \\ NY 14853, USA \\ * Correspondence: jillianlgoldfarb@gmail.com or goldfarb@cornell.edu; Tel.: +1-607-255-5789
}

Received: 28 September 2018; Accepted: 13 November 2018; Published: 17 November 2018

check for updates

\begin{abstract}
The volatility of crude oil prices incentivizes the use of domestic alternative fossil fuel sources such as oil shale. For ex situ oil shale retorting to be economically and environmentally viable, we must convert the copious amounts of semi-coke waste to an environmentally benign, useable by-product. Using acid and acid + base treatments, we increased the surface area of the semi-coke samples from $15 \mathrm{~m}^{2} / \mathrm{g}$ (pyrolyzed semi-coke) to upwards of $150 \mathrm{~m}^{2} / \mathrm{g}$ for hydrochloric acid washed semi-coke. This enhancement in porosity and surface area is accomplished without high temperature treatment, which lowers the overall energy required for such a conversion. XRD analysis confirms that chemical treatments removed the majority of dolomite while retaining other carbonate minerals and maintaining carbon contents of approximately $10 \%$, which is greater than many fly ashes that are commonly used as sorbent materials. $\mathrm{SO}_{2}$ gas adsorption isotherm analysis determined that a double $\mathrm{HCl}$ treatment of semi-coke produces sorbents for flue gas treatment with higher $\mathrm{SO}_{2}$ capacities than commonly used fly ash adsorbents. Computational fluid dynamics modeling indicates that the sorbent material could be used in a fixed bed reactor to efficiently remove $\mathrm{SO}_{2}$ from the gas stream.
\end{abstract}

Keywords: oil shale; semi-coke; activation; flue gas; sorbent; sulfur dioxide

\section{Introduction}

Over the past several decades, significant fluctuations in oil prices have motivated the search for alternative energy sources including both fossil and renewable fuels. One such alternative fossil fuel is oil shale, which is a sedimentary rock containing proportionally large amounts of kerogen or organic matter. Pyrolysis (heating in an oxygen-free environment) allows for the extraction of the confined kerogen from oil shale, which leaves compacted solid rock as a waste product. The separated organics are further converted to crude oil for various energy applications. The U.S. Geological Survey reports that overall U.S. oil shale reserves comprise about 2.6 trillion barrels of oil from which 1 trillion barrels are recoverable [1].

The waste rock left after kerogen recovery is known as semi-coke, which is a semi-carbonaceous char that poses an environmental threat [2]. Heavy metals, polycyclic aromatic hydrocarbons, and phenols present in the semi-coke can leach into groundwater and contaminate the surrounding areas. Semi-coke mountains created after oil shale extraction present a physical environmental danger [3-8]. Mountains of semi-coke dot the Estonian landscape where oil shale is used to generate a majority of the country's electricity. This makes identifying alternatives to open disposal 
environmentally necessary to address past use and economically necessary to enable future use in ex situ retorts. Transforming the solid waste remaining after oil extraction could improve the environmental—and fiscal—outlook for this alternative fossil fuel.

Prior research demonstrates the ability to convert the by-products of oil shale use-both ash and semi-coke-to sorbent systems. For example, the ash resulting from complete oil shale oxidation has shown promising adsorption abilities to remove pesticides from liquids [9]. Al-Asheh and co-workers were able to activate semi-coke with $\mathrm{CO}_{2}, \mathrm{ZnCl}_{2}$, and $\mathrm{OH}$ to remove phenols from liquid phases [10]. Yet, high amounts of heavy metals and polycyclic hydrocarbons present make the industrial use of semi-coke in aqueous solutions without further treatment questionable [11,12]. However, there is the possibility to utilize semi-coke for flue gas treatment if its surface area can be increased [1]. Specifically, it has been proposed that semi-coke could be used for industrial scale removal of $\mathrm{SO}_{2}, \mathrm{NO}_{\mathrm{x}}$, and $\mathrm{NH}_{3}$ from flue gas streams [13]. As suggested by Kaljuvee et al., the presence of carbonaceous materials in semi-coke makes it possible to adsorb large quantities of $\mathrm{SO}_{2}$ without the addition of $\mathrm{CaO}$ or limestone, which is usually used for sulfur emission control [14]. According to Yan et al., semi-coke activation with $\mathrm{HCl}$ and $\mathrm{KOH}$ allows $\mathrm{SO}_{2}$ gas to be adsorbed onto the surface of the semi-coke [15]. However, prior work details two difficulties in converting semi-coke to sorbents. These include dealing with the minerals naturally present in oil shale and costly processing steps-including additional heat inputs-to develop porosity and adsorption surface area to produce high-capacity flue gas sorbents [2].

This work examines the possibility of converting semi-coke waste from a U.S. domestic oil shale to a sorbent material for sulfur dioxide gas treatment via a low temperature activation (less than $100{ }^{\circ} \mathrm{C}$ ) process rather than the high temperature physical and chemical mechanisms that prevail in the literature $\left(500{ }^{\circ} \mathrm{C}\right.$ to $\left.900^{\circ} \mathrm{C}\right)[10,13,16-18]$, which saves on energy costs. In the present work, hydrochloric acid $(\mathrm{HCl})$ and potassium hydroxide $(\mathrm{KOH})$ are used as chemical treatments. Prior work shows that using $\mathrm{HCl}$ and $\mathrm{KOH}$ (and other acids and bases) in combination with high temperature treatment produces high surface area adsorbents at high energy penalties while developing hot caustic gases $[6,9,10]$. The present work is the first to demonstrate the potential to use low-temperature chemical activation of oil shale semi-coke to produce sorbent materials with adsorption capacities for $\mathrm{SO}_{2}$ higher than commonly used coal fly ashes. Using experimental data for $\mathrm{SO}_{2}$ adsorption to the oil shale sorbent, a computational fluid dynamics (CFD) model of a fixed bed reactor was developed to demonstrate the potential of the material for commercial scale up. This work demonstrates a novel, less energy intensive waste to by-product conversion technology for solid waste management that eliminates the need for current open air storage of semi-coke and that could enable domestic oil shale to generate its own materials for flue gas capture, which increases the economic and environmental viability of oil shale as an alternative fossil fuel.

\section{Materials and Methods}

Oil shale rocks were obtained from the Piceance Basin, Colorado, USA, part of the Uinta formation with an average Fisher Assay oil yield of 20-40 GPT [19]. A random sampling of heterogeneous rocks were crushed by using a hydraulic press into small $(<1 \mathrm{~cm})$ particles. These particles were further ground by using a planetary ball mill (Across International) and stainless steel milling balls for $1 \mathrm{~h}$ at $1200 \mathrm{rpm}$. The resulting powder was separated using ASTM brass sieves on a sieve shaker. Particles between 150 and $250 \mu \mathrm{m}$ were used in this study to (1) limit heat and mass transfer limitations during the simulated retorting [20], (2) to enable eventual production of a powdered activated sorbent material, and, (3) since it represented over $50 \mathrm{vol} \%$ of the ground particles, to yield sufficient experimental quantities. The raw sample was labeled "Oil Shale" (OS).

To extract oil from the oil shale (mimicking ex situ retorting via slow pyrolysis under laboratory controlled, reproducible processes as commonly done in the literature $[8,11,21])$, it was heated in a porcelain boat in a 2-inch horizontal tube furnace (MTI Corporation GSL-100X) under an inert high purity nitrogen atmosphere flowing at $100 \mathrm{~mL} / \mathrm{min}$. Samples were heated to $110^{\circ} \mathrm{C}$ and held for $30 \mathrm{~min}$ 
to remove residual moisture, and then heated to $600{ }^{\circ} \mathrm{C}$ at $10{ }^{\circ} \mathrm{C} / \mathrm{min}$ and held for one hour to extract kerogen. The resultant solid semi-carbonaceous "waste" particles were labeled "semi-coke" (SC).

\subsection{Chemical Activation}

Chemical activation of semi-coke with $\mathrm{HCl}$ and $\mathrm{KOH}$, which is usually followed by a heat treatment, is known to open pores and remove minerals, which would facilitate $\mathrm{SO}_{2}$ gas capture [4]. The oil shale semi-coke samples were subjected to three different chemical treatments: single $\mathrm{HCl}$, double $\mathrm{HCl}$, and $\mathrm{HCl}+\mathrm{KOH}$. First, semi-coke was washed with $2 \mathrm{M} \mathrm{HCl}$ (trace metal grade) for $2 \mathrm{~h}$ at $60^{\circ} \mathrm{C} ; 6 \mathrm{~mL}$ of $\mathrm{HCl}$ was used for every $1 \mathrm{~g}$ of semi-coke to completely submerge the samples. After soaking, they were vacuum filtered and dried overnight in a laboratory oven at $80^{\circ} \mathrm{C}$. This sample

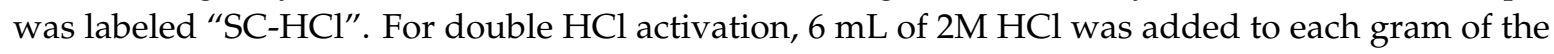
$\mathrm{SC}-\mathrm{HCl}$ sample, soaked at $60^{\circ} \mathrm{C}$ for $2 \mathrm{~h}$, and dried. This sample was named "SC-HCl-HCl".

In the case of $\mathrm{KOH}$ activation, a similar technique to Yan et al. was used [15] to determine the necessity of using a base treatment in addition to the acid treatment. In this case, samples treated once with $\mathrm{HCl}$ were immersed in $3 \mathrm{M} \mathrm{KOH}$ solution for $2 \mathrm{~h}$ at $6^{\circ} \mathrm{C}$. For every $1 \mathrm{~g}$ of a sample, $9 \mathrm{~mL}$ of $\mathrm{KOH}$ solution was used. Samples were then filtered and transferred into $1 \mathrm{M} \mathrm{HCl} \mathrm{solution}(1 \mathrm{~g}: 17 \mathrm{~mL})$ for $1 \mathrm{~h}$ at $80{ }^{\circ} \mathrm{C}$ to wash and remove residual potassium ions $\left(\mathrm{K}^{+}\right)$. This sample was named "SC-HCl- $\mathrm{KOH}^{\prime}$.

\subsection{Characterization of Activated Semi-Coke Samples}

The impact of the chemical treatments on the resulting activated semi-cokes was probed using a suite of characterization techniques. The BET surface areas were measured using an Autosorb-iQ (Quantachrome Instruments), according to established methods [6,11]. Additionally, 0.1-0.2 g of powder were outgassed at $180{ }^{\circ} \mathrm{C}$ overnight with the sample mass measured post-degas on a Sartorius semi-microbalance to the $\pm 0.1 \mathrm{mg}$. Nitrogen adsorption isotherms $(77 \mathrm{~K})$ were used to determine the surface area using a multi-point BET method. A total of 11 points were measured over a partial pressure range of $\mathrm{P} / \mathrm{P}_{0}=0.05-0.30$.

Thermal stability and proximate analysis were measured by thermo-gravimetric analysis (TGA) differential scanning calorimetry (DSC) (Mettler-Toledo TGA-DSC-1). Between 5 and $15 \mathrm{mg}$ of the sample were placed in $70 \mu \mathrm{L}$ alumina crucibles to measure the weight change as a function of temperature. The experiment was performed under a constant temperature ramp rate of $10^{\circ} \mathrm{C} / \mathrm{min}$. Samples were first heated to $110^{\circ} \mathrm{C}$ under a nitrogen atmosphere $(50 \mathrm{~mL} / \mathrm{min}$ flow with a $20 \mathrm{~mL} / \mathrm{min}$ $\mathrm{N}_{2}$ balance protective gas flow) and held at this temperature for $30 \mathrm{~min}$ to start with a dry baseline. After that, they were heated to $900{ }^{\circ} \mathrm{C}$ and held for $1 \mathrm{~h}$ under a nitrogen atmosphere. Mass loss at this temperature was attributed to volatile matter. The temperature was increased to $950{ }^{\circ} \mathrm{C}$ and air was introduced into the system to oxidize the samples for $10 \mathrm{~min}$. The oxidized mass loss is considered to be fixed carbon (entrained in mineral matter (e.g., $\mathrm{CaCO}_{3}$ ). The remaining mass is attributed to inorganic content, which is loosely called "ash".

Scanning Electron Microscopy (Zeiss Supra 55VP) was utilized to qualitatively observe the effects of acid-base activation treatments. Powder samples were placed on double-sided copper tape to insure conductivity and grounding. The change of mineral composition was determined by vertical powder $\mathrm{CuK} \alpha \mathrm{X}$-Ray diffraction at $40 \mathrm{kV}$ and $40 \mathrm{~mA}$ with a step size of $0.05^{\circ}$ and dwell time of $0.5 \mathrm{~s}$ (Bruker D8 Discover). Since the instrument operates vertically, the powder was affixed to the sample holder using Kapton tape. A diffraction pattern of pure Kapton tape was subtracted from the sample results.

\subsection{Application of Activated Semi-Coke to Flue Gas Treatment}

To determine the effectiveness of the proposed by-product conversion pathway, TGA was used to measure the rate and quantity of $\mathrm{SO}_{2}$ gas removed from a gas stream at various temperatures. A gas tank consisting of $2.026 \mathrm{~mol}^{\circ} \mathrm{SO}_{2}\left( \pm 0.02 \%\right.$ ) and balance ultra-high purity $\mathrm{N}_{2}$ (Airgas) was used as the inlet gas to the TGA at a flow rate of $50 \mathrm{~mL} / \mathrm{min}$. Carbonaceous (and semi-carbonaceous) materials are promising adsorbents at flue gas precipitator temperatures of $60-150{ }^{\circ} \mathrm{C}$ [22]. To ensure a constant 
baseline for all samples, moisture was removed by heating and holding samples at $110{ }^{\circ} \mathrm{C}$ under a nitrogen atmosphere for $30 \mathrm{~min}$, which was followed by heating/cooling of the sorbent sample to the desired temperature under $\mathrm{N}_{2}$. Upon reaching the desired temperature, the $\mathrm{SO}_{2}$ gas mixture was introduced into the TGA. The experiment was performed at $40^{\circ} \mathrm{C}, 60^{\circ} \mathrm{C}, 80^{\circ} \mathrm{C}, 110^{\circ} \mathrm{C}$, and $150{ }^{\circ} \mathrm{C}$ and held at these temperatures for $1 \mathrm{~h}$ to determine the amount of gas adsorbed to each material.

The kinetics of isothermal adsorption were fit to a second order equation.

$$
\frac{d q}{d t}=k\left(q_{e}-q\right)^{2}
$$

The linearized form of Equation (1) is shown below.

$$
\frac{t}{q_{t}}=\frac{1}{k q_{e}^{2}}+\frac{1}{q_{e}} t
$$

where $q_{e}$ and $q_{t}$ are the mass of $\mathrm{SO}_{2}$ adsorbed per gram of carbon $(\mathrm{mg} / \mathrm{g})$ at equilibrium and time $t$ (seconds), respectively, and $k\left(\mathrm{~s}^{-1}(\mathrm{mg} / \mathrm{g})^{-1}\right)$ is the rate constant. To determine the enthalpy and entropy of the adsorption, we use a linearized Arrhenius Equation.

$$
\ln (k)=\ln \left(k_{0}\right)-\frac{E_{a}}{R} \frac{1}{T}
$$

where $E_{a}$ is the activation energy $(\mathrm{kJ} / \mathrm{mol}), R$ is the universal gas constant $(8.314 \mathrm{~J} / \mathrm{mol} / \mathrm{K}), k_{0}$ is an independent temperature factor $\left(\mathrm{s}^{-1}(\mathrm{mg} / \mathrm{g})^{-1}\right)$, and $T$ is the absolute temperature $(\mathrm{K})$.

\subsection{Computational Modeling of $\mathrm{SO}_{2}$ Adsorption at a Pilot Scale}

To demonstrate the applicability of these semi-coke sorbents to remove $\mathrm{SO}_{2}$ from simulated flue gas streams at a pilot scale, we turn to computational fluid dynamics (CFD) modeling. The modeling was completed using OpenFOAM version 4.1, which is an open source CFD solver [23]. A two fluid model (TFM) was used to simulate a fixed bed reactor with the sorbent particles being one phase and the flue gas being the other. The TFM is a common method of modeling fluidized and fixed beds due to the similarities between fluid motion and particle interactions $[24,25]$ In the TFM, the governing equations are solved for each phase and the phases are coupled through constitutive relations such as the granular temperature and drag models. Detailed descriptions of the method and its validity for modeling fixed and fluidized beds can be found in the literature [26-28]. Other methods of solving multiphase systems such as the volume of the fluid (VOF) method use one set of governing equations with averaged properties from all the phases. Although VOF methods are popular in other applications, the TFM method is more effective for gas-particle systems because of the large differences in gas and particle motion within the system.

Before implementing the $\mathrm{SO}_{2}$ adsorption model in the OpenFOAM TFM code, the hydrodynamics and reactions implemented in the CFD model were verified by using two test cases. The first verifies the relationship between gas velocity and change in pressure across the bed, which, in a fixed bed, should be linear (as shown in Figure 1a, velocity and pressure were found to vary linearly over a range of velocities with an average error of $0.9 \%$ and a maximum error of $1.8 \%$ ). The second verification case considers the implementation of the reaction term. A reaction term with a simplified linear dependence on $\mathrm{SO}_{2}$ concentration was tested at low gas flows and steady state conditions. For this case, an analytical solution can be derived from the mass transfer equation.

$$
\frac{\partial(\alpha \rho)}{\partial t}+\vec{u} \nabla \cdot(\alpha \rho)=\nabla^{2} \rho+R
$$

where $R=Q \alpha$ and takes the form shown below. 


$$
\alpha(y)=\alpha_{0} e^{\frac{Q}{u \rho} y}
$$

where $Q$ is a constant reaction coefficient, $u$ is the velocity, $\alpha$ is the volumetric concentration of $\mathrm{SO}_{2}$ in the gas, $\rho$ is density, $y$ is the position in the bed, and $\alpha_{0}$ is the $\mathrm{SO}_{2}$ concentration at the inlet. As seen in Figure $1 \mathrm{~b}$, the CFD simulation predicts the $\mathrm{SO}_{2}$ concentration over the bed with almost no deviation from the analytical solution.

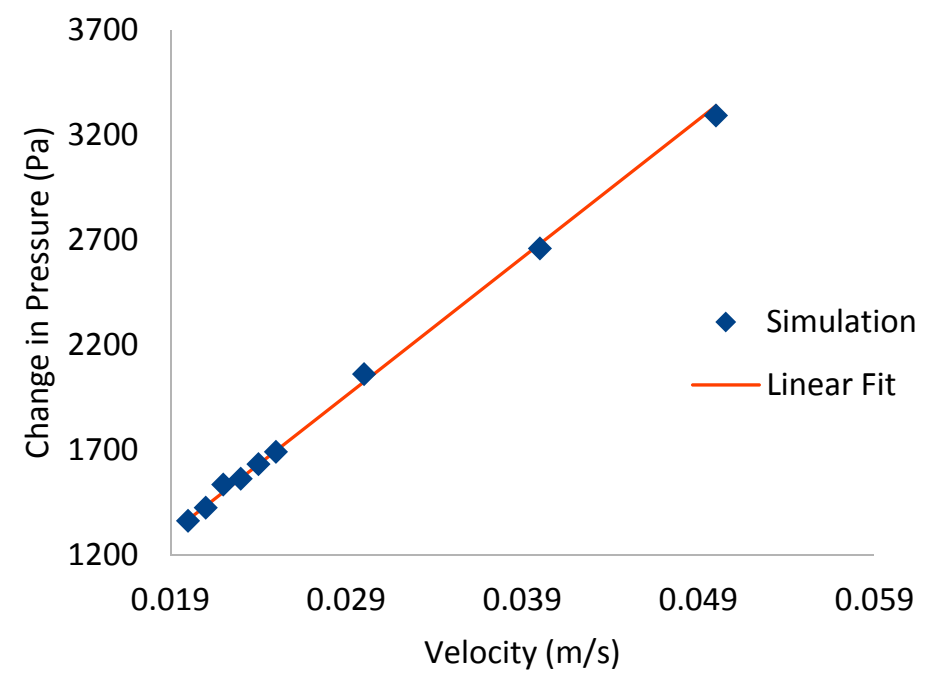

(a) Relationship between pressure and gas inlet velocity plotted against a linear fit.

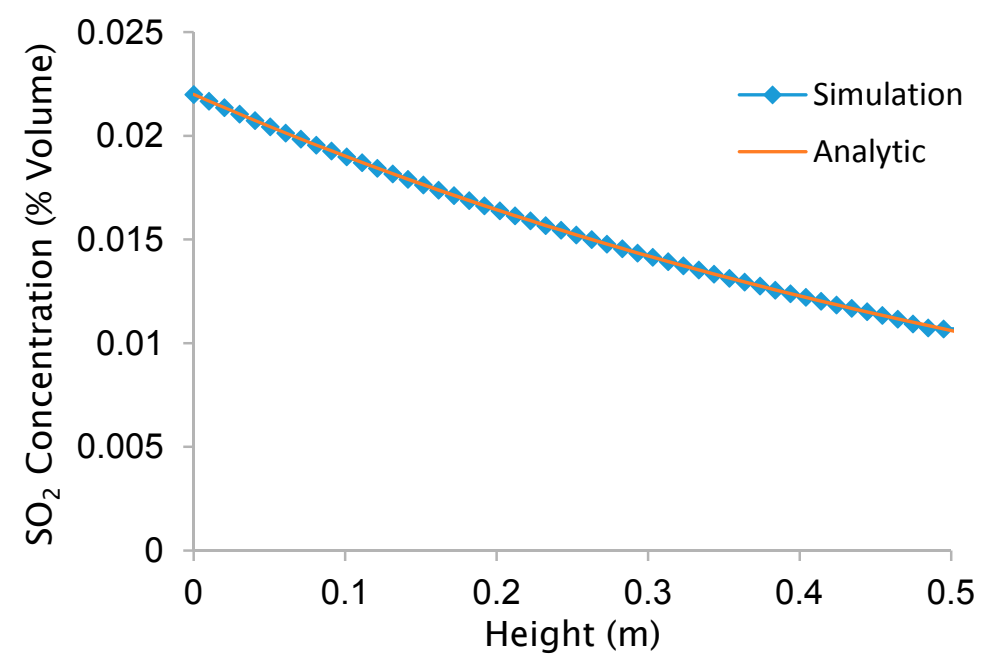

(b) Change in $\mathrm{SO}_{2}$ concentration across the bed with a linear reaction term.

Figure 1. Verification of the computational model for fluidized bed hydrodynamics and a reaction term.

Based on these two cases, we verified that the TFM model can simulate the hydrodynamics of a fixed bed with the implementation of the multiphase reaction term. For the sorbent materials fabricated and characterized in this paper, the CFD model is used to demonstrate their use on a pilot scale system. The CFD model implements the reactions outlined in Section 2.3 for the source term $R$ from Equations (4) and (5), which is shown below.

$$
\frac{\partial(\alpha \rho)}{\partial t}+\vec{u} \nabla \cdot(\alpha \rho)=\nabla^{2} \rho+\frac{k q_{e}^{2} t}{1+k q_{e} t}
$$


To investigate the ability of semi-coke to adsorb $\mathrm{SO}_{2}$ on a larger scale, the double $\mathrm{HCl}$ semi-coke was simulated at varying temperatures and velocities and the $\mathrm{SO}_{2}$ breakthrough curves are compared for each condition. The reactions were modeled to represent the semi-coke performance after the initial start-up was completed. The simulations were brought to steady flow conditions prior to the addition of any reaction terms to best represent the conditions in the physical experiments.

\section{Results and Discussion}

While most techniques to "activate" semi-carbonaceous materials in the literature use high temperatures to increase surface area and capacity, the present investigation probes the feasibility of using low-temperature activation to convert a U.S. oil shale semi-coke to a sorbent material for the removal of $\mathrm{SO}_{2}$ from flue gases. This byproduct conversion could potentially reduce the environmental burden and increase the economic feasibility of this alternative fossil fuel.

\subsection{Impact of Activation on Semi-Coke}

As shown in Table 1, the surface area of oil shale semi-coke increases with progressive low-temperature treatments. The starting surface area of the raw shale is relatively low but doubles upon pyrolysis. When kerogen is removed during extraction, the pores of the remaining semi-carbonaceous solid open [1]. Treatment with $\mathrm{HCl}$ increases the surface area six-fold while decreasing the volatile carbon content (as compared to semi-coke). The decrease in the amount of volatile matter is likely due to the acid etching a portion of the carbon present and the increase in surface area likely due to dissolution of the carbonate materials opening pore spaces [1]. BET surface areas increase with further chemical treatments from $89 \mathrm{~m}^{2} / \mathrm{g}$ for single $\mathrm{HCl}$ treatment to a high of $159 \mathrm{~m}^{2} / \mathrm{g}$ for the double $\mathrm{HCl}$ activation method. This is likely due to the partial reduction of mineral content. We probe this proposed explanation using TGA and XRD to describe the materials' composition.

Table 1. Surface area and carbon contents of raw, semi-coke and demineralized samples $( \pm 1$ standard deviation).

\begin{tabular}{ccccc}
\hline Sample & $\begin{array}{c}\text { BET Surface Area } \\
\mathbf{m}^{\mathbf{2}} \mathbf{g}\end{array}$ & $\begin{array}{c}\text { Volatile Carbon } \\
\mathbf{w t} \%\end{array}$ & $\begin{array}{c}\text { Fixed Carbon } \\
\mathbf{w t} \%\end{array}$ & $\begin{array}{c}\text { Ash } \\
\mathbf{w t} \%\end{array}$ \\
\hline OS & $8.2 \pm 0.3$ & $21.24 \pm 0.40$ & $0.28 \pm 0.01$ & $78.48 \pm 1.49$ \\
SC & $15.4 \pm 1.3$ & $13.50 \pm 0.26$ & $0.36 \pm 0.03$ & $86.14 \pm 1.64$ \\
SC-HCl & $89.0 \pm 1.5$ & $9.37 \pm 0.17$ & $0.30 \pm 0.01$ & $90.33 \pm 1.11$ \\
SC-HCl-HCl & $159.2 \pm 3.2$ & $9.77 \pm 0.88$ & $1.12 \pm 0.03$ & $89.11 \pm 8.50$ \\
SC-HCl-KOH & $123.7 \pm 4.1$ & $7.34 \pm 0.49$ & $1.03 \pm 0.07$ & $91.63 \pm 6.12$ \\
\hline
\end{tabular}

The results of the thermogravimetric analysis under pyrolysis conditions are presented in Figure 2 to provide a comparison of thermal stability [29,30]. At temperatures above $200{ }^{\circ} \mathrm{C}$, organic matter is lost. We see a sharp decrease in mass up to $700{ }^{\circ} \mathrm{C}$ with a peak temperature of about $680^{\circ} \mathrm{C}$ for OS and SC samples, which is shown in the derivative thermogravimetric (DTG) curves. As seen in Figure 2a, only the raw and pyrolyzed samples show significant mass loss while activated ones do not have intense changes in mass. This suggests that the chemical treatments removed some volatile compounds from the samples. DTG curves show no peak (therefore, we present only DTG curves for oil shale and semi-coke). Since the raw sample contains minerals and organic matter in a heterogeneous matrix, there are three peaks in mass loss rate at $420^{\circ} \mathrm{C}, 480^{\circ} \mathrm{C}$, and $680^{\circ} \mathrm{C}$. For the pyrolyzed sample, we only see a peak at $670{ }^{\circ} \mathrm{C}$. Since this sample was already heated to $600{ }^{\circ} \mathrm{C}$, the majority of the volatiles are driven out of the sample and, thus, we would only expect to see a peak above the pyrolysis temperature. The largest peaks for the semi-coke may indicate the presence of minerals, which are subsequently removed with chemical activation since the DTG curves show no peaks. 


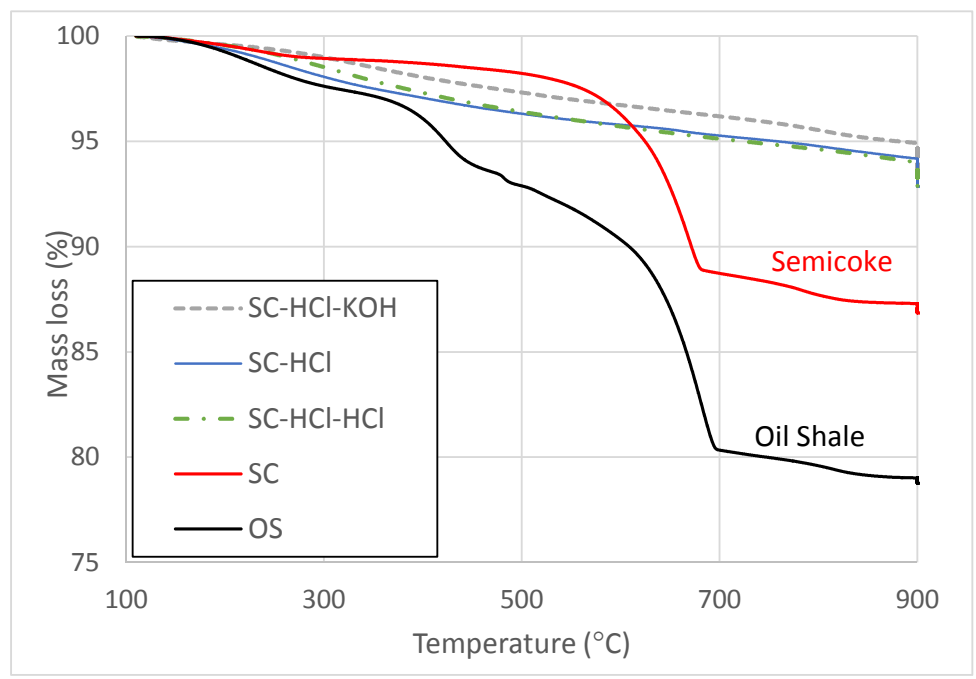

(a) TG curves.

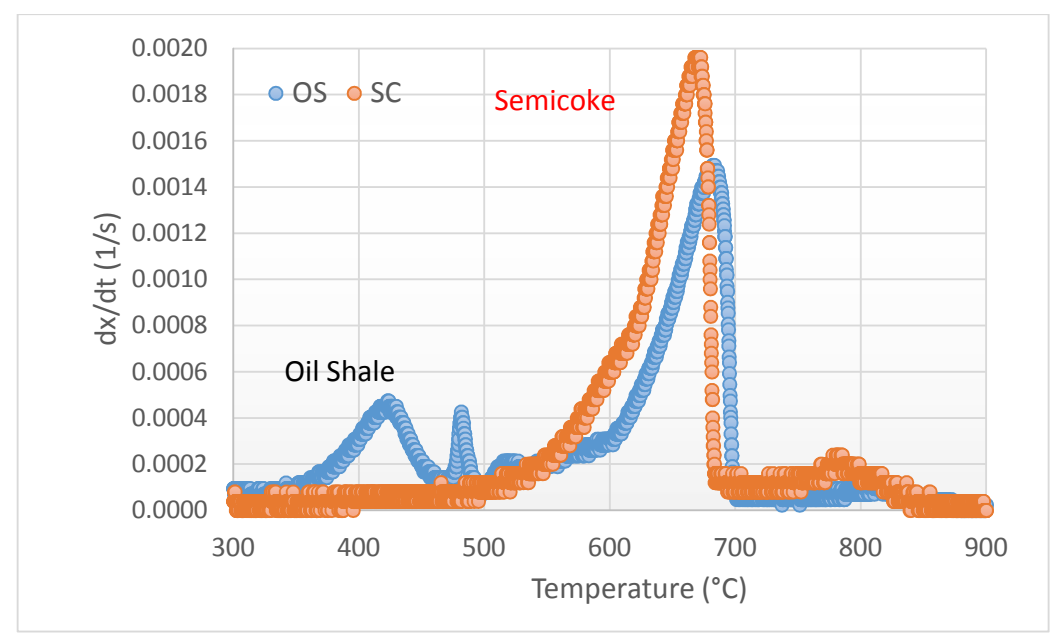

(b) DTG curves of oil shale and semi-coke (treated samples show no DTG peak).

Figure 2. Thermogravimetric analysis of raw, pyrolyzed, and demineralized samples for pyrolysis of samples at $10^{\circ} \mathrm{C} / \mathrm{min}$ under high purity nitrogen.

Scanning Electron Microscopy images are shown in Figure 3. Qualitatively, we see an amorphous structure with large particles for the oil shale, which gives low surface area and high volatile carbon content as discussed. Overall, the chemically activated samples show similar morphology with porous void spaces and moderately less amorphous character than the raw oil shale, which is supported by the increase in surface area.

Figure 4 shows the crystallographic structures present in powdered samples and the relative impact of the activation treatments on demineralization of the semi-coke samples. We note that the signals for some minor peaks are not identifiable given the heterogeneity and small concentrations in the samples. This analysis is to understand the overarching crystallinity changes in the samples. The oil shale diffraction pattern contains strong peaks for dolomite and calcite compounds, which indicates elevated concentrations of these minerals in the oil shale rock. When the shale is pyrolyzed, some of the minerals are removed by heat treatment, which was also noted by prior research in the field [1]. The acid-base activation increases the relative quartz concentration in the samples. Since no silicon compounds were added during activation, the increase in quartz concentration is relative with respect to the decrease in other minerals' concentration. The XRD analysis software identified some peaks in the raw sample as pollucite (shown in Figure 4 as $x$ ). Given that pollucite is a zeolite material that is 
not normally naturally occurring, we suspect it may be an isomer such as analcime with Na rather than Cs [31].

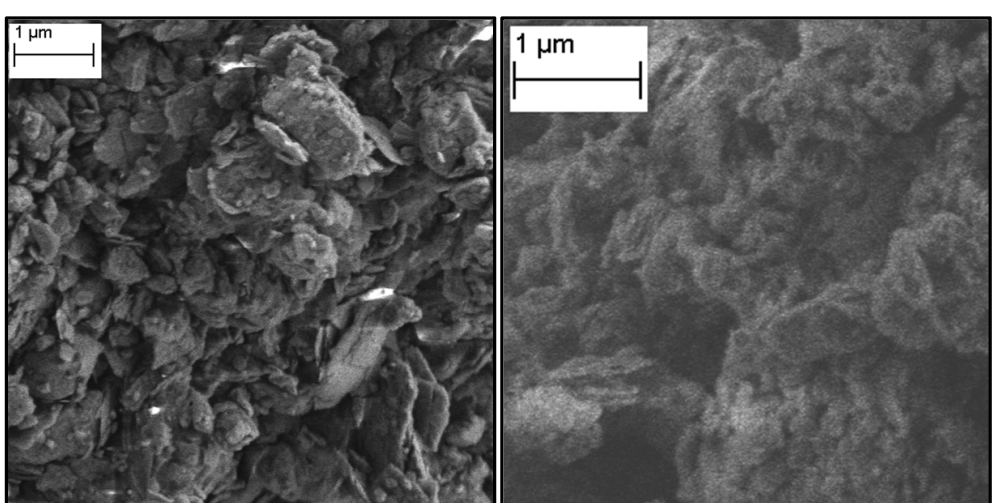

(a) OS

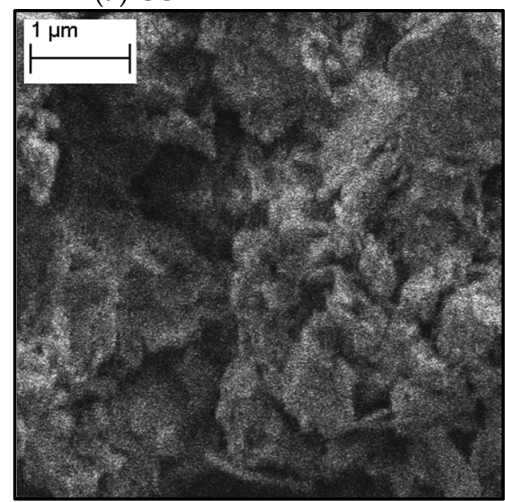

(d) $\mathrm{SC}-\mathrm{HCl}-\mathrm{KOH}$

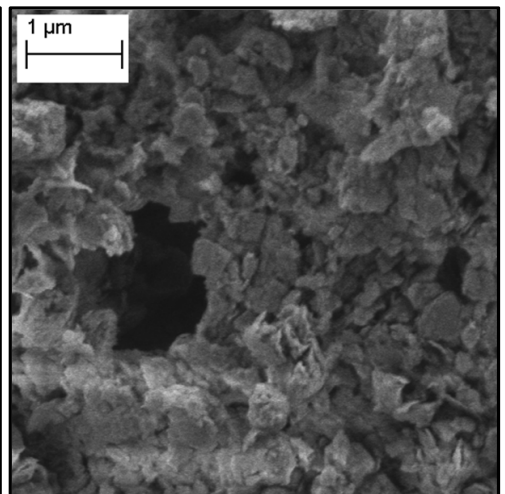

(c) $\mathrm{SC}-\mathrm{HCl}$

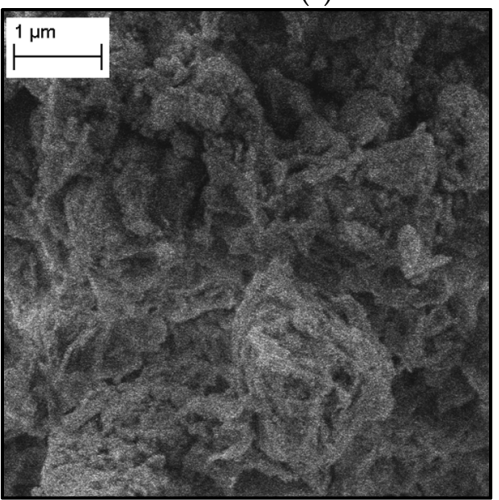

(e) $\mathrm{SC}-\mathrm{HCl}-\mathrm{HCl}$

Figure 3. SEM images of oil shale samples at 10,000 magnification to illustrate increasing chemical treatment on development of porosity and loss of crystalline "structured" components (scale bar indicates $1 \mu \mathrm{m})$.

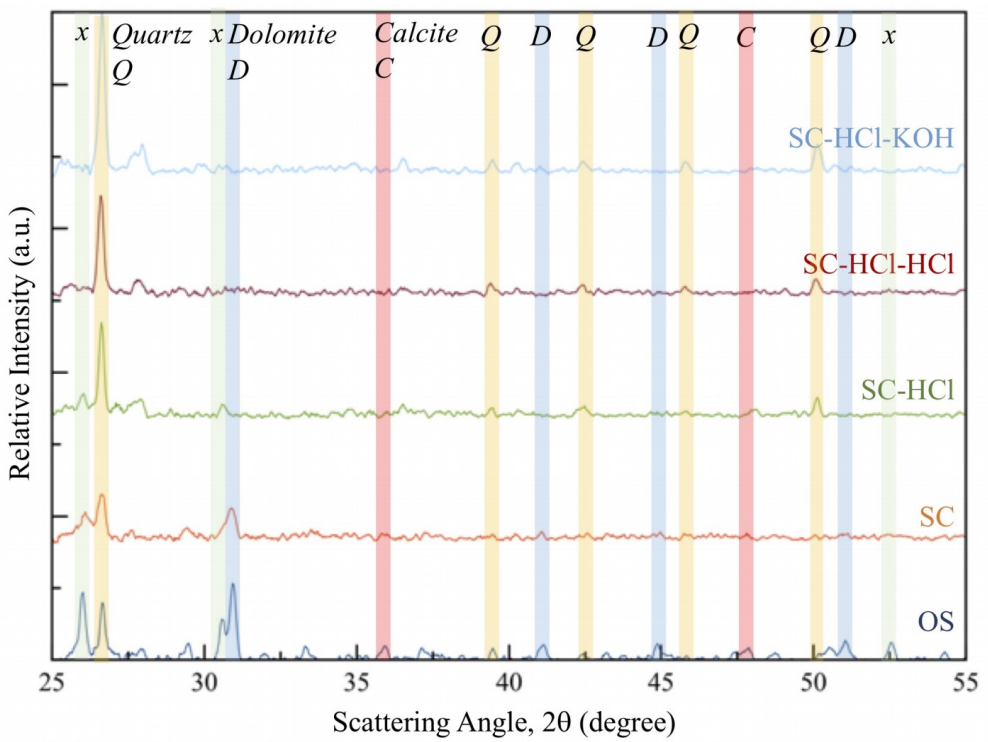

Figure 4. $\mathrm{Cu}-\mathrm{K} \alpha \mathrm{X}$-ray diffraction pattern of raw, semi-coke, and demineralized samples. $\mathrm{Q}$, D, and C indicate Quartz, Dolomite, and Calcite, respectively. $x$ was suggested by analysis software as pollucite, which is unlikely given its zeolite structure and non-natural occurrence. 


\subsection{Ability of Semi-Coke Sorbents to Adsorb $\mathrm{SO}_{2}$}

The results of the thermogravimetric analysis for $\mathrm{SO}_{2}$ gas adsorbed at five temperatures are shown in Figure 5. As noted in the literature, carbonaceous materials are predominantly responsible for $\mathrm{SO}_{2}$ gas adsorption [14]. Therefore, we normalize milligrams of gas adsorbed per gram of carbon (fixed carbon + volatile matter) present. The isotherms can be divided into two regions with fast adsorption in the beginning and slow adsorption thereafter. The initial rates for fast adsorption are presented in Table 2. The transition between regions was considered to be the change in slope of the adsorption data away from the near vertical, which is shown in Figure 5a. The cut-off for this transition can be seen in Figure $5 \mathrm{a}$ and estimated from Table 2. For example, the initial rate for $\mathrm{SC}-\mathrm{HCl}, 60^{\circ} \mathrm{C}$ adsorption is $30 \mathrm{mg} / \mathrm{g}_{\mathrm{C}} / \mathrm{min}$, and the amount adsorbed over this first rate is $30 \mathrm{mg} / \mathrm{g}_{\mathrm{C}}$, which makes this first adsorption step 1 minute long. The initial adsorption rates are quite close for all samples at a given temperature (e.g., at $40^{\circ}$, the uptake rate is 27,28 , and $34 \mathrm{mg} / \mathrm{g}_{\mathrm{C}} / \mathrm{min}$ for the SC-HCl, SC-HCl-HCl , and $\mathrm{SC}-\mathrm{HCl}-\mathrm{KOH}$ samples, respectively). The $\mathrm{SO}_{2}$ uptake rate during this initial stage increased for all three samples from $40{ }^{\circ} \mathrm{C}$ to $60^{\circ} \mathrm{C}$ adsorption conditions but then decreased as the temperature increased. As seen in Figure $5 \mathrm{~b}$, the highest adsorption capacities were at the lowest temperature for all samples and they decreased as the temperature increased. It is well established that lower temperatures are more conducive to adsorption [13,30,32-34].

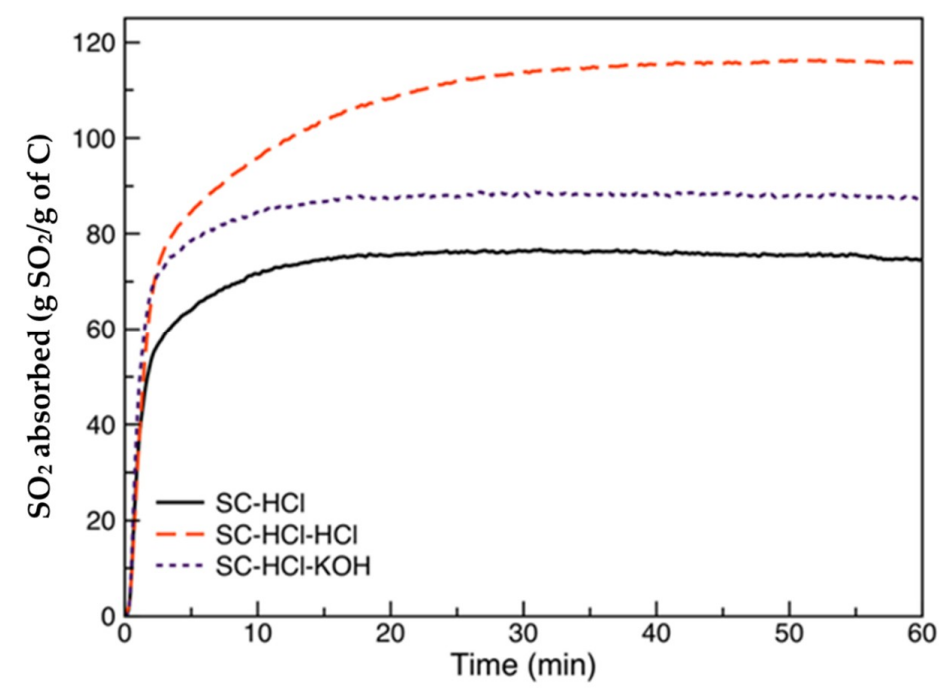

(a) Adsorption isotherm data for $\mathrm{SO}_{2}$ to activated semi-coke samples.

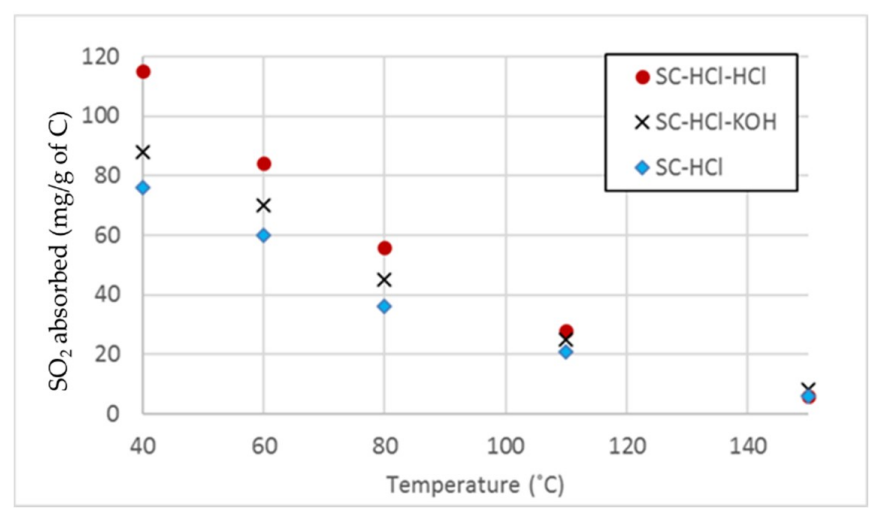

(b) Isothermal adsorption capacity of $\mathrm{SO}_{2}$ to activated samples $\left(\mathrm{mg} / \mathrm{g}\right.$ of $\left.{ }^{\circ} \mathrm{C}\right)$.

Figure 5. Isothermal adsorption of $\mathrm{SO}_{2}$ to activated semi-coke samples. 
Table 2. Initial fast adsorption rates for $\mathrm{SO}_{2}$ capture on activated semi-cokes ( \pm 1 standard deviation).

\begin{tabular}{|c|c|c|c|c|c|c|}
\hline \multirow{2}{*}{$\begin{array}{l}\text { Adsorption } \\
\text { Temperature } \\
{ }^{\circ} \mathrm{C}\end{array}$} & \multicolumn{2}{|c|}{ SC-HCl } & \multicolumn{2}{|c|}{ SC-HCl-HCl } & \multicolumn{2}{|c|}{ SC-HCl-KOH } \\
\hline & $\begin{array}{l}\text { Adsorption } \\
\text { Uptake Rate } \\
\mathrm{mg} /\left(\mathrm{g}_{\mathrm{C}}\right) / \mathrm{min}\end{array}$ & $\begin{array}{c}\mathrm{SO}_{2} \\
\text { Adsorbed } \\
\mathrm{mg} /\left(\mathrm{g}_{\mathrm{C}}\right)\end{array}$ & $\begin{array}{l}\text { Adsorption } \\
\text { Uptake Rate } \\
\mathrm{mg} /\left(\mathrm{g}_{\mathrm{C}}\right) / \mathrm{min}\end{array}$ & $\begin{array}{c}\mathrm{SO}_{2} \\
\text { Adsorbed } \\
\mathrm{mg} /\left(\mathrm{g}_{\mathrm{C}}\right)\end{array}$ & $\begin{array}{l}\text { Adsorption } \\
\text { Uptake Rate } \\
\mathrm{mg} /\left(\mathrm{g}_{\mathrm{C}}\right) / \mathrm{min}\end{array}$ & $\begin{array}{c}\mathrm{SO}_{2} \\
\text { Adsorbed } \\
\mathrm{mg} /\left(\mathrm{g}_{\mathrm{C}}\right)\end{array}$ \\
\hline 40 & $27 \pm 0.3$ & $53 \pm 1.064$ & $28 \pm 0.2$ & $71 \pm 0.9$ & $34 \pm 0.1$ & $68 \pm 0.488$ \\
\hline 60 & $30 \pm 0.7$ & $30 \pm 1.106$ & $30 \pm 0.7$ & $60 \pm 2.3$ & $64 \pm 1.3$ & $45 \pm 1.543$ \\
\hline 80 & $10 \pm 0.5$ & $28 \pm 2.44$ & $17 \pm 0.2$ & $42 \pm 0.9$ & $13 \pm 0.6$ & $38 \pm 2.862$ \\
\hline 110 & $9.2 \pm 0.5$ & $13 \pm 1.159$ & $11 \pm 0.7$ & $19 \pm 2.2$ & $9.1 \pm 0.4$ & $19 \pm 1.494$ \\
\hline 150 & $2.1 \pm 0.1$ & $5.3 \pm 0.496$ & $2.3 \pm 0.2$ & $5.7 \pm 0.9$ & $2.9 \pm 0.1$ & $6.2 \pm 0.409$ \\
\hline
\end{tabular}

After this initial fast adsorption period, the maximum amount of $\mathrm{SO}_{2}$ adsorbed was achieved after about $15 \mathrm{~min}$ for all samples (at which point, the mass remained constant for all samples for the next $\sim 40 \mathrm{~min}$ ). The total amount of $\mathrm{SO}_{2}$ adsorbed depends on the activation treatment, which is shown in Table 3, with SC-HCl-HCl having the highest adsorption capacity at each temperature. This second, slow isotherm region persists for a much longer period than the fast absorption region and, as such, is considered the normal operating region for the sorbent material in a pilot or commercial scale reactor (and is, therefore, used in the CFD models).

Table 3. Rate constants and activation energies for pseudo-second-order kinetics of adsorption of $\mathrm{SO}_{2}$ onto demineralized samples (experimental values \pm 1 standard deviation) (used in computational modeling to represent pilot scale operating conditions).

\begin{tabular}{|c|c|c|c|}
\hline Adsorption Temperature ${ }^{\circ} \mathrm{C}$ & $\begin{array}{l}\mathrm{q}_{\mathrm{e}}, \operatorname{Exp} \\
\mathrm{mg} /\left(\mathrm{g}_{\mathrm{C}}\right)\end{array}$ & $\begin{array}{c}\mathrm{q}_{\mathrm{e}}, \text { Model } \\
\mathrm{mg} /\left(\mathrm{g}_{\mathrm{C}}\right)\end{array}$ & $\underset{\left(g_{C}\right) / m g / m i n}{k}$ \\
\hline \multicolumn{4}{|c|}{$\mathrm{SC}-\mathrm{HCl}$} \\
\hline 40 & $76 \pm 2$ & 79 & $1.3 \times 10^{-2} \pm 1.1 \times 10^{-3}$ \\
\hline 60 & $60 \pm 3$ & 63 & $9.9 \times 10^{-3} \pm 2.4 \times 10^{-3}$ \\
\hline 80 & $36 \pm 4$ & 36 & $6.3 \times 10^{-2} \pm 7.3 \times 10^{-4}$ \\
\hline 110 & $21 \pm 2$ & 22 & $6.7 \times 10^{-2} \pm 1.8 \times 10^{-3}$ \\
\hline $\mathrm{E}_{\mathrm{a}}$ & \multicolumn{3}{|c|}{$28.9 \pm 0.7 \mathrm{~kJ} / \mathrm{mol}$} \\
\hline \multicolumn{4}{|c|}{ SC-HCl-HCl } \\
\hline 40 & $115 \pm 3$ & 122 & $3.9 \times 10^{-3} \pm 9.1 \times 10^{-4}$ \\
\hline 60 & $84 \pm 1$ & 86 & $1.4 \times 10^{-2} \pm 1.2 \times 10^{-3}$ \\
\hline 80 & $56 \pm 2$ & 57 & $2.6 \times 10^{-2} \pm 4.4 \times 10^{-4}$ \\
\hline 110 & $28 \pm 1$ & 26 & $4.0 \times 10^{-2} \pm 7.1 \times 10^{-4}$ \\
\hline $\mathrm{E}_{\mathrm{a}}$ & \multicolumn{3}{|c|}{$32.5 \pm 1.3 \mathrm{~kJ} / \mathrm{mol}$} \\
\hline \multicolumn{4}{|c|}{ SC-HCl-KOH } \\
\hline 40 & $88 \pm 1$ & 91 & $1.6 \times 10^{-2} \pm 5.2 \times 10^{-4}$ \\
\hline 60 & $70 \pm 3$ & 72 & $1.2 \times 10^{-2} \pm 7.3 \times 10^{-4}$ \\
\hline 80 & $45 \pm 2$ & 46 & $4.4 \times 10^{-2} \pm 8.3 \times 10^{-4}$ \\
\hline 110 & $25 \pm 2$ & 27 & $4.2 \times 10^{-2} \pm 1.0 \times 10^{-3}$ \\
\hline $\mathrm{E}_{\mathrm{a}}$ & \multicolumn{3}{|c|}{$17.3 \pm 1.1 \mathrm{~kJ} / \mathrm{mol}$} \\
\hline
\end{tabular}

A pseudo-second order kinetic model describes the adsorption isotherms quite well in the second adsorption region. A plot of $t / q_{t}$ versus time results in a straight line fit with a regression coefficient of at least 0.999 for all data (with the exception of $150{ }^{\circ} \mathrm{C}$ ). The theoretical $q_{e}$ (maximum adsorption), experimental $q_{e}$, and corresponding second order rate constants for the slower adsorption region are presented in Table 3. Only the values for isotherms conducted between 40 and $110{ }^{\circ} \mathrm{C}$ are reported since there is negligible adsorption capacity at $150{ }^{\circ} \mathrm{C}$, which leads to a poor fit of the kinetic model. Additionally, activation energies are calculated based on the second order rate constants by plotting $\ln (\mathrm{k})$ versus $1 / \mathrm{T}$ where the slope gives an estimate of the activation energy presented in Table 3 . Anecdotally, the desorption of $\mathrm{SO}_{2}$ was monitored via TGA since every sample was ramped down to 
$25{ }^{\circ} \mathrm{C}$ under a high flow of $\mathrm{N}_{2}(100 \mathrm{~mL} / \mathrm{min})$ at the completion of every experiment. All samples lost at least $97 \%$ of the $\mathrm{SO}_{2}$ within five minutes of the temperature reaching $30^{\circ} \mathrm{C}$ (the high flow rate of $\mathrm{SO}_{2}$-free gas shifting the equilibrium to draw $\mathrm{SO}_{2}$ to the gas phase), which suggests a strong possibility for reuse and regeneration via simple temperature or pressure swing desorption. This will be explored further in future work.

The SC-HCl-HCl semi-coke shows the highest adsorption capacity among the three chemically treated samples. We note that surface area might be the reason for the enhanced adsorption since we see the same trend for the BET surface area and maximum amount of $\mathrm{SO}_{2}$ adsorbed (SC-HCl-HCl $>\mathrm{SC}-\mathrm{HCl}-\mathrm{KOH}>\mathrm{SC}-\mathrm{HCl}$ ). Kisiela et al. compared the adsorption abilities of activated lignite fly ash and industrially available sorbents at $100{ }^{\circ} \mathrm{C}$ with a maximum of $4.5 \mathrm{mg} \mathrm{SO} \mathrm{S}_{2}$ per $\mathrm{g}$ of sample on activated coke [35], which is used industrially in hazardous waste plants [36]. Martyniuk et al. note an adsorption capacity of up to $30 \mathrm{mg} / \mathrm{g}$ of $\mathrm{SO}_{2}$ at $20{ }^{\circ} \mathrm{C}$ and $20 \mathrm{mg} / \mathrm{g}$ of $\mathrm{SO}_{2}$ at $100{ }^{\circ} \mathrm{C}$ onto a char produced from ortho-coking coal at $600{ }^{\circ} \mathrm{C}$ [32]. As such, the semi-coke sorbents produced here at low temperature demonstrate higher adsorption capacities than many previously demonstrated waste-to-sorbent converted materials. We turn to CFD models to probe the applicability of these semi-coke samples to industrially relevant flue gas treatment.

\subsection{Simulated Pilot Scale Removal of $\mathrm{SO}_{2}$ Using Semi-Coke Sorbents}

The CFD simulation described in Section 2.4 is used to simulate a pilot scale system and demonstrate the ability of the semi-coke sorbents to effectively remove $\mathrm{SO}_{2}$ from a representative flue gas stream. A pilot scale fixed bed reactor was simulated. The reactor is $0.45 \mathrm{~m}$ by $2 \mathrm{~m}$ and is initiated with a particle bed $1 \mathrm{~m}$ deep and $0.2 \mathrm{~mm}$ particle size, which is shown in Figure 6 . The simulation was initialized without $\mathrm{SO}_{2}$ until steady state flow conditions were reached at which point, a mixture of nitrogen and $2.026 \%$ (by volume) $\mathrm{SO}_{2}$ was introduced at the inlet and run until about $50 \%$ of the $\mathrm{SO}_{2}$ escaped the bed. As described in Section 3.2, the reaction is based on the experimental pseudo-second order kinetic model and uses the parameters from Table 3 for the reaction rates and adsorption capacity.

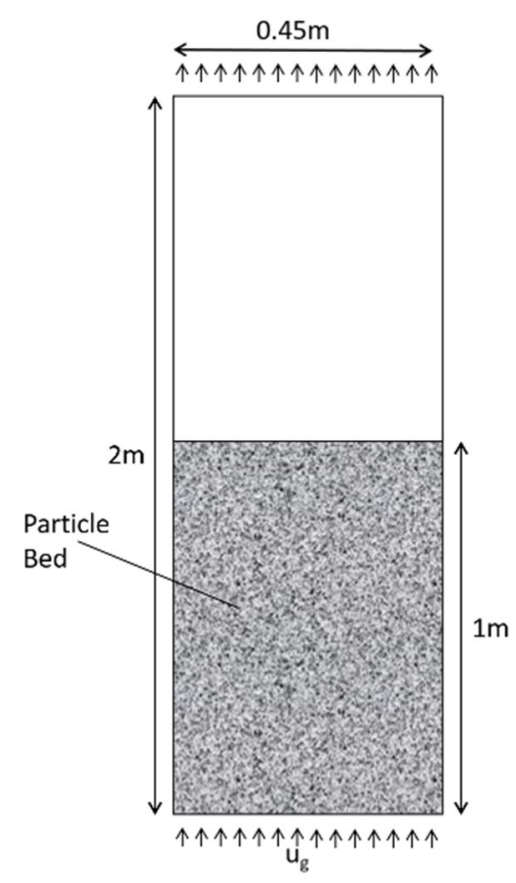

Figure 6. Schematic of initial setup for pilot scale simulation. The gray shaded area represents the region in which sorbent particles are originally placed.

Figure 7 shows the distribution of $\mathrm{SO}_{2}$ throughout the bed at several snapshots in time. At $t=$ $0, \mathrm{SO}_{2}$ is introduced to the bed and, by roughly $12 \mathrm{~s}$, the bed reaches a breakthrough point where 
approximately $10 \%$ of the $\mathrm{SO}_{2}$ is leaving the bed. This is due to the saturation of sorbent particles in the bed. At lower velocities, the residence time of $\mathrm{SO}_{2}$ in the bed is longer, which allows even more $\mathrm{SO}_{2}$ to be adsorbed by the sorbent particles and breakthrough to be reached even sooner.

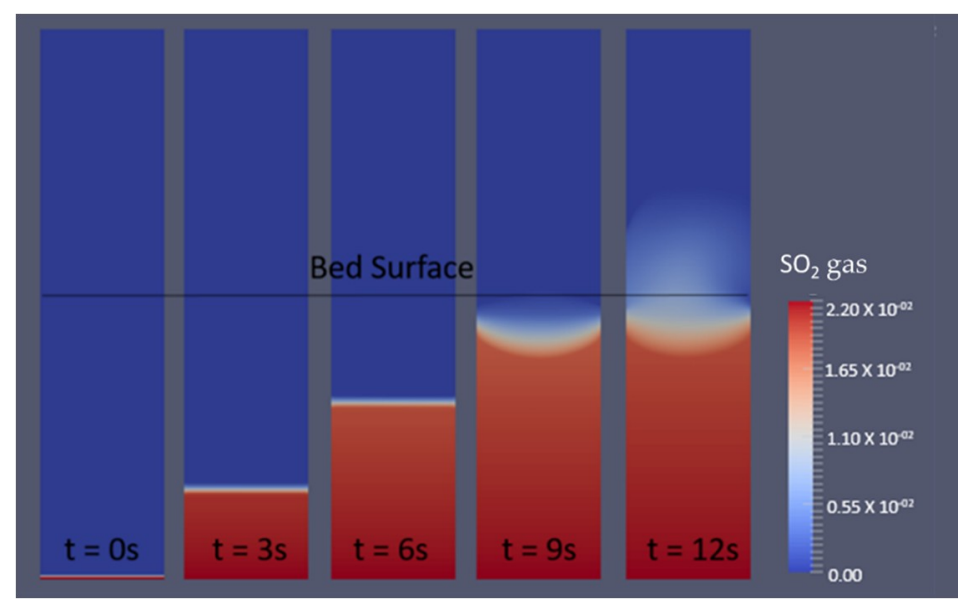

Figure 7. Time progression of $\mathrm{SO}_{2}$ at $60^{\circ} \mathrm{C}$ with a velocity of $0.1 \mathrm{~m} / \mathrm{s}$. The dark line indicates the top of the particle bed.

The simulations also show that lower temperatures show a higher adsorption capability and a slower reaction rate. In the experimental data, it is shown that the equilibrium $\mathrm{SO}_{2}$ adsorption is much higher at $40{ }^{\circ} \mathrm{C}$ than at $60^{\circ} \mathrm{C}$. This indicates that the sorbent has a higher $\mathrm{SO}_{2}$ capacity at $40{ }^{\circ} \mathrm{C}$ than at $60^{\circ} \mathrm{C}$. However, when the adsorption rate $(k)$ is considered, which increases with a rising temperature, we find that the time needed for adsorption increases. Thus, while the lower temperatures can adsorb more $\mathrm{SO}_{2}$, the higher temperatures successfully adsorb more $\mathrm{SO}_{2}$ in a shorter period. This can be seen in Figure 8 where the concentration across the bed at a specific time is shown for $40^{\circ} \mathrm{C}$ and $60^{\circ} \mathrm{C}$.

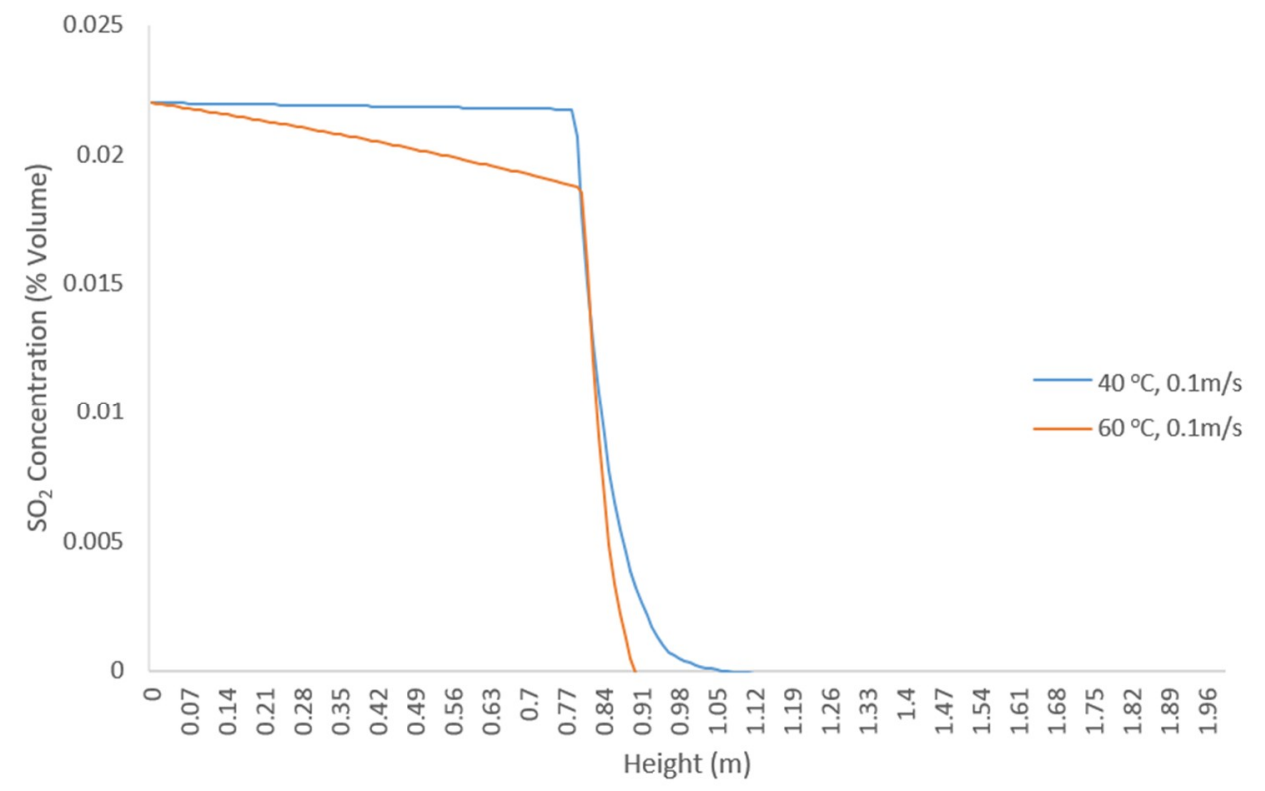

Figure 8. Comparison of $\mathrm{SO}_{2}$ concentration across the bed between $40{ }^{\circ} \mathrm{C}$ and $60{ }^{\circ} \mathrm{C}$ at a velocity of $0.1 \mathrm{~m} / \mathrm{s}$.

In Figure 9, the time taken for $10 \%$ of the $\mathrm{SO}_{2}$ to escape the particle bed is plotted against the inlet velocity of the gas. Time in the figure begins at the end of the start-up period when the $\mathrm{SO}_{2}$ started flowing through the bed. As seen in Figure 9, it takes longer for the $\mathrm{SO}_{2}$ to break the top of the bed 
at $60{ }^{\circ} \mathrm{C}$ than it does at $40{ }^{\circ} \mathrm{C}$. At high velocities, for both temperatures, the time taken for the $\mathrm{SO}_{2}$ to break the bed surface is approximately the same as the time it would take the $\mathrm{SO}_{2}$ to reach the top of an empty bed without adsorption. This indicates that a slower velocity is needed to ensure $\mathrm{SO}_{2}$ capture. In the design of the pilot system, the CFD model can be used to optimize a bed design based on temperature and flow rate. As seen in these preliminary CFD simulations, there are tradeoffs between the capacity and the flow rate.

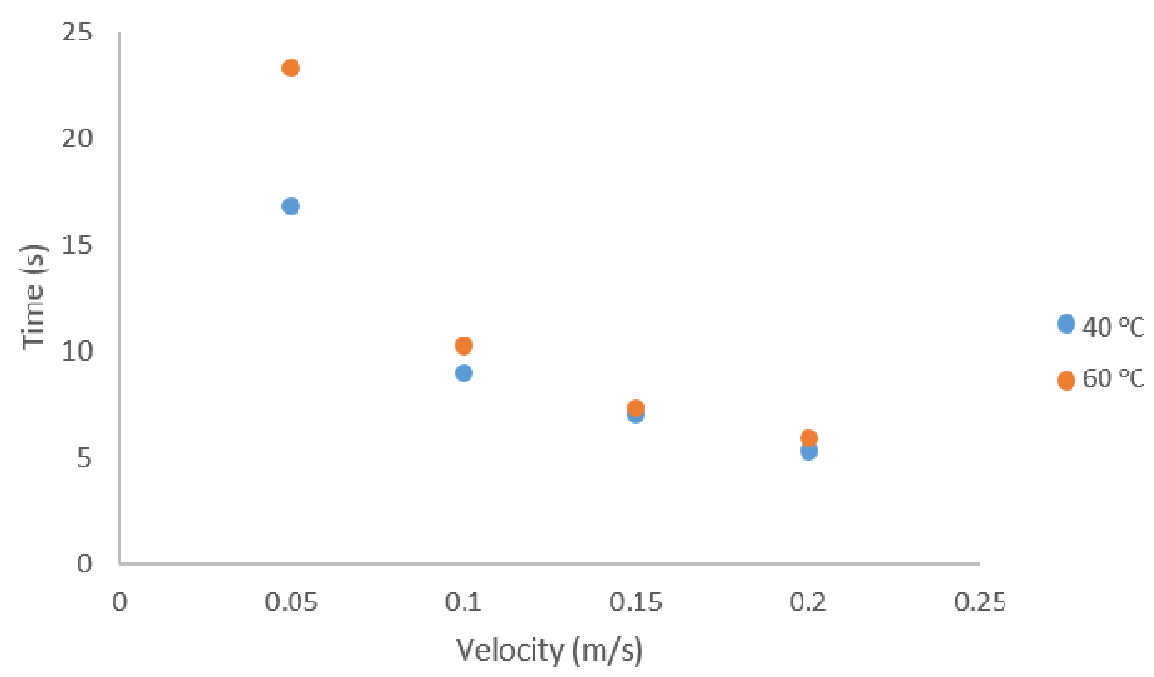

Figure 9. Time taken for $10 \%$ of the $\mathrm{SO}_{2}$ to break through the top of the bed.

\section{Conclusions}

The present work demonstrates the potential to use a low-temperature treatment method to convert oil shale semi-coke-an environmentally hazardous waste-to a flue gas adsorbent at considerably less harsh conditions than current conditions proposed in the literature. The activation treatments lead to a large increase in surface area, which range from 6 to 11 times higher than the raw semi-coke. Flue gas adsorption experiments conducted via TGA demonstrate the possible use of the chemically activated samples for $\mathrm{SO}_{2}$ gas adsorption. Approximately $120 \mathrm{mg}$ of $\mathrm{SO}_{2}$ gas per gram of carbon present in the sorbent can be adsorbed at $40{ }^{\circ} \mathrm{C}$. Among the three different activation procedures, a double $\mathrm{HCl}$ treatment shows the greatest adsorption capacity, which is considerably higher than many coal-based materials currently used for flue gas treatment.

The CFD simulations demonstrate the ability of the sorbent materials to remove $\mathrm{SO}_{2}$ from a flue gas mixture in a fixed bed. The simulations show that the choice of operating temperature and velocity is a tradeoff between overall capacity and residence time. Future work will explore the scalability of the proposed byproduct conversion pathway by using expanded CFD simulations and adsorption-desorption experiments. Continuing experimental work on the process design for byproduct conversion should consider the composition and potential for recycling the $\mathrm{HCl}$ stream, the optimization of $\mathrm{HCl}$ concentration and temperature, and desorption studies for regeneration and reuse of the sorbent.

Author Contributions: The following contributions were made by each author. K.D.: Responsible for computational model, validation of model with experimental data, computational figures. E.M.R.: Supervisor for K.D., re-drafted computational results and discussion, and validated computational models. A.S.: Performed experimental work and data analysis, drafted portions of introduction, and made experimental figures. J.L.G.: Supervisor for A.S., drafted introduction and experimental results and discussion, validated experimental work, and ran statistical analyses.

Funding: Partial funding for this research was provided by a Clare Boothe Luce Foundation Graduate Fellowship.

Conflicts of Interest: The authors declare no conflict of interest. 


\section{References}

1. Vyas, A.; Xue, J.; Goldfarb, J.L. Improving the Environmental and Economic Viability of U.S. Oil Shale via Waste-to-Byproduct Conversion of Semicoke to Sorbents. Energy Fuels 2016, 30, 188-195. [CrossRef]

2. Brendow, K. Global Oil Shale Issues and Perspectives. In Proceedings of the Synthesis of the Symposium on Oil Shale, Tallinn, Estonia, 18-19 November 2002.

3. Datangel, B.; Goldfarb, J.J.L. Heavy Metals in Colorado and Chinese Oil Shale Semicoke: Disposal Issues, Impediments to Byproduct Conversion. Energy Fuels 2011, 25, 3522-3529. [CrossRef]

4. Han, X.X.; Jiang, X.M.; Cui, Z.G. Study of the Combustion Mechanism of Oil Shale Semicoke in a Thermogravimetric Analyzer. J. Therm. Anal. Calorim. 2008, 92, 595-600. [CrossRef]

5. Kahru, A.; Põllumaa, L. Environmental Hazard of the Waste Streams of Estonian Oil Shale Industry: An Excotoxicological Review. Oil Shale 2006, 23, 53-93.

6. Trikkel, A.; Kuusik, R.; Martins, A.; Pihu, T.; Stencel, J.M. Utilization of Estonian Oil Shale Semicoke. Fuel Process. Technol. 2008, 89, 756-763. [CrossRef]

7. Wang, Q.; Sun, B.; Wu, X.; Bai, J.; Sun, J. Influence of Retorting Temperature on Combustion Characteristics and Kinetic Parameters of Oil Shale Semicoke. Oil Shale 2006, 23, 328-339.

8. Goldfarb, J.L.; D'Amico, A.; Culin, C.; Suuberg, E.M.; Külaots, I. Oxidation Kinetics of Oil Shale Semicokes: Reactivity as a Function of Pyrolysis Temperature and Shale Origin. Energy Fuels 2013, 27, 666-672. [CrossRef]

9. Al-Qodah, Z.; Shawaqfeh, A.T.; Lafi, W.K. Adsorption of Pesticides from Aqueous Solutions Using Oil Shale Ash. Desalination 2007, 208, 294-305. [CrossRef]

10. Al-Asheh, S.; Banat, F.; Masad, A. Physical and Chemical Activation of Pyrolyzed Oil Shale Residue for the Adsorption of Phenol from Aqueous Solutions. Environ. Geol. 2003, 44, 333-342. [CrossRef]

11. Külaots, I.; Goldfarb, J.L.; Suuberg, E.M. Characterization of Chinese, American and Estonian Oil Shale Semicokes and Their Sorptive Potential. Fuel 2010, 89, 3300-3306. [CrossRef]

12. Nicolini, J.; Pereira, B.F.; Pillon, C.N.; Machado, V.G.; Lopes, W.A.; de Andrade, J.B.; Mangrich, A.S. Characterization of Brazilian Oil Shale Byproducts Planned for Use as Soil Conditioners for Food and Agro-Energy Production. J. Anal. Appl. Pyrolysis. 2011, 90, 112-117. [CrossRef]

13. Liu, Q.; Li, C.; Li, Y. SO $\mathrm{SO}_{2}$ Removal from Flue Gas by Activated Semi-Cokes: 1 . The Preparation of Catalysts and Determination of Operating Conditions. Carbon 2003, 41, 2217-2223. [CrossRef]

14. Kaljuvee, T.; Kuusik, R.; Trikkel, A. $\mathrm{SO}_{2}$ Binding into the Solid Phase during Thermooxidation of Blendsestonian Oil Shale Semicoke. J. Therm. Anal. Calorim. 2003, 72, 393-404. [CrossRef]

15. Yan, Z.; Liu, L.; Zhang, Y.; Liang, J.; Wang, J.; Zhang, Z.; Wang, X. Activated Semi-Coke in $\mathrm{SO}_{2}$ removal from Flue Gas: Selection of Activation Methodology and Desulfurization Mechanism Study. Energy Fuels 2013, 27, 3080-3089. [CrossRef]

16. Li, J.; Kobayashi, N.; Hu, Y. The Activated Coke Preparation for $\mathrm{SO}_{2}$ Adsorption by Using Flue Gas from Coal Power Plant. Chem. Eng. Process. Process Intensif. 2008, 47, 118-127. [CrossRef]

17. Liu, Q.; Guan, J.S.; Li, J.; Li, C. $\mathrm{SO}_{2}$ Removal from Flue Gas by Activated Semi-Cokes: 2. Effects of Physical Structures and Chemical Properties on $\mathrm{SO}_{2}$ Removal Activity. Carbon 2003, 41, 2225-2230. [CrossRef]

18. Shangguan, J.; Li, C.H.; Miao, M.Q.; Yang, Z. Surface Characterization and $\mathrm{SO}_{2}$ Removal Activity of Activated Semi-Coke with Heat Treatment. New Carbon Mater. 2008, 23, 37-43. [CrossRef]

19. Self, J.G.; Brownfield, M.E.; Johnson, R.C.; Mercier, T.J. Fischer Assay Histograms of Oil Shale Drill Cores and Cuttings from the Uinta Basin, Utah and Colorado. Available online: https: / / www.google.com.tw / url? sa=t\&rct=j\&q=\&esrc=s\&source=web\&cd=1\&cad=rja\&uact=8\&ved= 2ahUKEwiworSMu9DeAhWKgrwKHfiDBXYQ7gEwAHoECAkQCA\&url=https\%3A\%2F\%2Ftranslate. google.com.tw $\% 2$ Ftranslate $\% 3 F h 1 \% 3 D z h-T W \% 26 s 1 \% 3 D e n \% 26 u \% 3 D h t t p s \% 3 A \% 2 F \% 2 F p u b s . u s g s$. gov\%2Fdds\%2Fdds-069\%2Fdds-069-bb\%2FREPORTS\%2F69_BB_CH_5.pdf\%26prev\%3Dsearch\&usg= AOvVaw2zVMPts0VZ6mIlrN8UHXT1 (accessed on 27 September 2018).

20. Patnaik, A.S.; Goldfarb, J.L. Continuous Activation Energy Representation of the Arrhenius Equation for the Pyrolysis of Cellulosic Materials: Feed Corn Stover and Cocoa Shell Biomass. Cellul. Chem. Technol. 2016, 50, 311-320.

21. Williams, P.T.; Ahmad, N. Influence of Process Conditions on the Pyrolysis of Pakistani Oil Shales. Fuel 1999, 78, 653-662. [CrossRef]

22. Richter, E. Carbon Catalysts for Pollution Control. Catal. Today 1990, 7, 93-112. [CrossRef] 
23. Weller, H.; Greenshields, C.; de Rouvray, C. OpenFOAM v.4.1. 2016. Available online: https:/ / openfoam. org/version/4-1/ (accessed on 27 September 2018).

24. Hoomans, B.P.B.; Kuipers, J.A.M.; Briels, W.J.; van Swaaij, W.P.M. Discrete Particle Simulation of Bubble and Slug Formation in a Tow-Dimensional Gas-Fluidised Bed: A Hard Sphere Approach. Chem. Eng. Sci. 1996, 51, 99-118. [CrossRef]

25. van der Hoef, M.A.; van Sint Annaland, M.; Kuipers, J.A.M. Computational Fluid Dynamics for Dense Gas-Solid Fluidized Beds: A Multi-Scale Modeling Strategy. Chem. Eng. Sci. 2004, 59, 5157-5165. [CrossRef]

26. Ergun, S. Fluid Flow through Packed Columns. Chem. Eng. Progr. 1952, 48, 89-94.

27. Gidaspow, D. Multiphase Flow and Fluidization: Continuum and Kinetic Theory Descriptions; Academic Press: San Diego, CA, USA, 1994.

28. Wen, C.Y.; Yu, Y.H. A Generalized Method for Predicting the Minimum Fluidization Velocity. AIChE J. 1966, 610-612. [CrossRef]

29. Miao, Z.; Wu, G.; Li, P.; Zhao, N.; Wang, P.; Meng, X. Combustion Characteristics of Daqing Oil Shale and Oil Shale Semi-Cokes. Min. Sci. Technol. 2009, 19, 380-384. [CrossRef]

30. Sun, B.Z.; Wang, Q.; Shen, P.Y.; Qin, H.; Li, S.H. Kinetic Analysis of Co-Combustion of Oil Shale Semi-Coke with Bituminous Coal. Oil Shale 2012, 29, 63-75. [CrossRef]

31. Jing, Z.; Cai, K.; Li, Y.; Fan, J.; Zhang, Y.; Miao, J.; Chen, Y.; Jin, F. Hydrothermal Synthesis of Pollucite, Analcime and Their Solid Solutions and Analysis of Their Properties. J. Nucl. Mater. 2017, 488, 63-69. [CrossRef]

32. Martyniuk, H.; Wieckowska, J. The Effect of Coal Rank and Carbonization Temperature on $\mathrm{SO}_{2}$ Adsorption Properties of Coal Chars. Fuel 1997, 76, 563-565. [CrossRef]

33. Davini, P. Adsorption of Sulphur Dioxide on Thermally Treated Active Carbon. Fuel 1989, 68, 145-148. [CrossRef]

34. Lisovskii, A.; Shter, G.; Semiat, R.; Aharoni, C. Adsorption of Sulfur Dioxide by Active Carbon Treated by Nitric Acid: II. Effect of Preheating on the Adsorption Properties. Carbon 1997, 35, 1645-1648. [CrossRef]

35. Kisiela, A.M.; Czajka, K.M.; Moroń, W.; Rybak, W.; Andryjowicz, C. Unburned Carbon from Lignite Fly Ash as an Adsorbent for $\mathrm{SO}_{2}$ Removal. Energy 2016, 116, 1454-1463. [CrossRef]

36. Jastrzab, K. Properties of Activated Cokes Used for Flue Gas Treatment in Industrial Waste Incineration Plants. Fuel Process. Technol. 2012, 101, 16-22. [CrossRef] 